\title{
LOAD-BEARING MASONRY TECHNOLOGY: SUCCESS FACTORS AND CHALLENGES OF IMPLEMENTATION IN THE MALAYSIAN CONSTRUCTION INDUSTRY
}

\author{
Mohd Nasrun Mohd Nawi ${ }^{1 *}$, Che Sobry Abdullah ${ }^{1}$, Nor Azlinda Ramli ${ }^{1}$, \\ Mohd Hanizan Zalazilah ${ }^{1}$, Ahmad Yusni Bahauddin ${ }^{1}$ \\ ${ }^{1}$ Disaster Management Institute, School of Technology Management and Logistics, Universiti Utara \\ Malaysia, Sintok, Kedah, 06010, Malaysia
}

(Received: July 2018 / Revised: September 2018 / Accepted: December 2018)

\begin{abstract}
This study aims to identify the success factors and challenges of implementing load-bearing masonry (LBM) technology in the Malaysian construction industry. The success factors and challenges of implementing LBM technology have been identified in previous literature. Further, this research has been carried out in which interviews were conducted to explore the real-life construction situation in Malaysia. The findings indicate that the success factors for LBM-technology implementation are organizational readiness, good collaboration, easier to install, skilled labor, continuous improvement of knowledge, excellent work coordination, improved efficiency of construction work, and environmentally friendly methods. The issues faced by construction firms, however, are related to a lack of knowledge, expertise, and government incentives and promotion as well as a lack of local demand. Based on these findings, it can be agreed that all the factors gathered from the previous literature are significantly related to the success factors and challenges in this study. Further study should be performed to improve the understanding of success factors and challenges on LBM-technology implementation.
\end{abstract}

Keywords: Construction industry; Industrialised Building System (IBS); Load-bearing masonry (LBM) technology

\section{INTRODUCTION}

Load-bearing masonry (LBM) technology is a simple construction method. There are two LBM construction techniques in which bricks are joined with mortar and without mortar mix to make a wall and building structure. Plain masonry, reinforced masonry, and interlocking bricks are examples of masonry technology structure. It have been manufactured at factories and then assembled at the construction site with minimal work.

The Construction Industry Development Board (CIDB) has categorized the interlocking brick system as a part of an Industrialised Building System (IBS) type that can replace the traditional method. Implementation of LBM technology is an alternative method to conventional reinforced frameworks in the completion of construction projects. LBM technology is an effective method to reduce materials on site, speed up construction work, cut down costs, and provide safe practices for the environment (Ramli et al., 2014). The application of LBM technology is not being rapidly adopted in the Malaysian construction industry even though the

*Corresponding author's email: nasrun@uum.edu.my, Tel. +604-9284773, Fax. +604-9284756

Permalink/DOI: https://doi.org/10.14716/ijtech.v9i8.2757 
advantages of the technology are evident. According to a study by Ramli et al., (2017), only $20 \%$ of developers use this technology in their housing projects, even though this technology can enhance production and improve a firm's performance. The construction industry requires a dynamic change to encourage a new mindset and move forward competitively with the technology industry. This study explores the success factors and challenges of LBM-technology implementation. Understanding the success factors of the firms that implement this technology in their projects can serve as a guide for future adopters of LBM technology, and identifying the challenges is crucial to overcoming existing problems and improving LBM technology among industry players. This research has been conducted in order to identify the success factors and challenges of LBM technology in Malaysia through a case study.

\subsection{Success Factors in the Implementation of LBM Technology}

This section discusses the success factors of LBM technology based on previous literature. The success factors of the implementation of LBM technology are as follows:

\subsubsection{Organizational readiness}

Organizational readiness refers to the availability of resources needed for the implementation of LBM technology. It also means that the organization has three key resources: technology, finance, and staff (Shah Alam, 2009). Organizational readiness plays an important role and can improve the confidence level of industry players in implementing LBM technology in construction projects.

\subsubsection{Good collaboration among team members}

Good collaboration among team members will solve potential problems related to the sequence and complex interfacing of the work process (Kamar et al., 2010; Baharuddin et al., 2015). Effective collaboration and cooperation between all team members in the technological process and construction work are crucial to ensure the success of LBM implementation in a project (Ismail et al., 2012).

\subsubsection{Easy installation}

According to Ramli et al. (2017), organizations believe that LBM technology is easy to use and install. When a technology such as LBM is perceived to be simple and easy to use, it is likely to be accepted by construction laborers.

\subsubsection{Skilled labor}

Skilled laborers are supported by quality training and education, especially among workers involved in LBM design such as brick layers (Ramli et al., 2016a; Thanoon et al., 2003).

\subsubsection{Continuous improvement of knowledge}

This is important in order to improve performance and achieve long-term success. The stakeholders should continue to improve their knowledge and skills in using LBM technology (Ramli et al., 2016a).

\subsubsection{Good work coordination}

Team members should be involved from the planning stages by working with the designer to ensure that all members understand the schematics drawing. They should also have good coordination with the manufacturing, transportation, and installation processes to ensure the success of the implementation (Lessing et al., 2005).

\subsubsection{Improving the efficiency of construction work}

According to Majid (1997), LBM technology has the potential to improve the efficiency of construction work through the elimination of formwork, reduced period of construction's site activities, and reduced costs while maintaining high quality. These methods were chosen because of the simple techniques required in laying bricks with less mortar, allowing variations of workmanship (Adedeji, 2012). 


\subsubsection{Environmentally friendly methods}

The components are manufactured in a factory, enabling higher quality control and environmentally friendly practices compared to on-site construction. Bricks are manufactured in factories and then assembled at the construction site. Sharath et al. (2013) stated that the masonry technology produces small-scale construction, making it self-sustained.

\subsection{Challenges for the Implementation of LBM Technology}

In general, challenges and barriers are defined as components that contribute to ineffective results or the poor success of a construction project (Baharuddin et al., 2016a). According to previous studies (Abdullah et al., 2009; Ramli et al., 2016b), there are three main challenges found regarding LBM technology: a lack of knowledge and expertise, a lack of promotion and incentive, and a lack of local demand.

\subsubsection{Lack of knowledge and expertise}

Nowadays, most of the industry's key actors are unaware of the existence of LBM technology. This lack of knowledge and exposure among industry players has led to the low popularity of LBM-technology use compared to conventional methods. A lack of expertise in LBM technology also remains, as many in the construction industry are still unfamiliar with this technology. According to Ramli et al. (2016a), expertise, especially in design, is crucial for the success of LBM-technology implementation.

\subsubsection{Lack of promotion and incentive}

Abdullah et al., (2015) discovered that LBM technology is still not widely used due to a lack of incentives. The government, through responsible authorization, should increase the incentives and promotion of LBM implementation. The lack of incentives and promotion is reflected in a low number of industry players who have adopted the technology (Ramli et al., 2016b).

\subsubsection{Lack of local demand}

According to Ramli et al. (2014), low awareness and a lack of local demand for LBM technology makes it critically challenging for this technology to penetrate Malaysia. The smallscale nature of LBM projects demonstrates that this technology is less popular and less indemand in Malaysia compared to conventional methods.

\section{METHODS}

The main objective of this research is to offer insight into the experiential perceptions of LBM technology by various practitioners in the Malaysian construction industry. It focuses on the success factors and challenges of LBM-technology implementation in Malaysian projects. A case study methodology has been chosen as the research approach because the data collected reflects real-life situations and current events. As argued by Yin (2015), a case study is conducted to answer the question of what is being studied and to have an in-depth understanding of the phenomenon of interest. The analysis has been carried out by comparing the success factors and challenges identified in previous studies with evidence gathered from current episodes in the construction industry.

This case study was carried out in Malaysia from January to March 2018. Data collection included semi-structured interviews, observations, and references to documentation. To ensure the reliability and validity of the data, the selection criteria for each respondent is based on the respondents' experiences with and knowledge of LBM technology. Four companies fulfilled the selection criteria: two contractor companies, one consultant company, and one developer company.

\subsection{Data Analysis}

Semi-structured interview protocols were designed in four sections: (1) respondent information; (2) company background; (3) success factors in LBM technology implementation; and (4) 
challenges of LBM technology implementation.

Based on the demographic results, all respondents have more than 10 years of experience with LBM-technology implementation in housing projects. Two respondents were categorized as small companies that employ fewer than 30 workers. Two other companies were classified as class F contractors. Respondents and their backgrounds are listed in Table 1.

Table 1 Respondents backgrounds

\begin{tabular}{|c|c|c|c|c|}
\hline No & $\begin{array}{c}\text { Type of } \\
\text { Company }\end{array}$ & Designation & $\begin{array}{c}\text { Experience in LBM } \\
\text { Technology }\end{array}$ & $\begin{array}{c}\text { Company Size/ } \\
\text { Classification }\end{array}$ \\
\hline 1. & Contractor & Project Manager & 10 years & Class F \\
\hline 2. & Contractor & $\begin{array}{l}\text { Assistant Project } \\
\text { Manager }\end{array}$ & 10 years & Class F \\
\hline 3. & Consultant & Engineer & 15 years & 1-20 employees \\
\hline 4. & Developer & Project Manager & 10 years & 1-30 employees \\
\hline
\end{tabular}

\section{RESULT AND DISCUSSION}

\subsection{Success Factors of LBM Technology Implementation}

Based on the interviews, the success factors are summarized in Table 2. All respondents shared a similar list of success factors. Respondents agreed that organizational readiness - such as having an experienced workforce, technical capabilities, and knowledgeable staff - are main success factors for adopting this technology in their construction projects. When further interviewed, respondents stated that they were confident with their companies' resources and abilities to utilize this technology. The consultant company also claimed that they have an expert team in the design and consultant services of LBM technology.

The results show that collaboration from all team members is crucial to a project's success. Respondents also indicated that collaboration between all parties will reduce interacting problems and ensure a smoother workflow that is on schedule. The two contractors stated that they are involved in design and have in-house construction teams, so they are capable of managing and organizing a project's schedule, controlling the supply chain, and having good communication channels between team members and everyone else involved. Moreover, the consultant and developer stated that good cooperation between all parties is an important success factor of LBM-technology implementation. All team members should have a clear idea of the construction process, understanding their functions and responsibilities while always sharing information with each other.

All the respondents claimed that LBM technology is a simple technique and easy to understand. Respondents chose this technology because it allows for easy installation in construction projects. Based on the results, LBM methodologies, such as the interlocking brick system, seem to be similar to the concept behind Lego bricks where workers lay each brick according to documented specifications. However, skilled workers are important in this work process, requiring continuous training, especially in brick-laying and -positioning.

The respondents agreed that LBM technology increases work efficiency as well as company performance. Utilization of LBM technology resulted in reduced construction times and costs. The contractor indicated that a single housing unit now takes about three months shorter period of time than conventional method. Cost reduction is based on the main materials used, specifically the elimination of framework and a minimal number of Reinforced concrete RC bars used. From the consultant's calculations, the cost was reduced by $15-20 \%$. 
Finally, the utilization of LBM technology reduced the environmental impact of construction work. Respondents claimed that manufactured components enabled higher quality control compared to conventional methods. The installation of the materials was more manageable because of the minimal material used in construction. Thus, LBM could reduce on-site waste, increase on-site safety, and improve air quality.

The results show eight critical success factors in the implementation of LBM technology: organizational resources, good team collaboration, easier installation, skilled labor, continuous improvement of knowledge, good work coordination, improved efficiency of construction, and environmentally friendly construction methods.

Table 2 Success factors for LBM-technology implementation

\begin{tabular}{|c|c|c|c|c|}
\hline Success Factors & Company 1 & Company 2 & Company 3 & Company 4 \\
\hline $\begin{array}{l}\text { Organizational } \\
\text { resources }\end{array}$ & Yes & Yes & Yes & Yes \\
\hline $\begin{array}{l}\text { Good collaboration } \\
\text { with team }\end{array}$ & Yes & Yes & Yes & Yes \\
\hline Easier to install & Yes & Yes & Yes & Yes \\
\hline $\begin{array}{l}\text { Skilled labor for site } \\
\text { installation }\end{array}$ & Agree & Agree & Agree & Agree \\
\hline $\begin{array}{l}\text { Continuous } \\
\text { improvement of } \\
\text { knowledge }\end{array}$ & Agree & Agree & Agree & Agree \\
\hline $\begin{array}{l}\text { Good work } \\
\text { coordination }\end{array}$ & Yes & Yes & Yes & Yes \\
\hline $\begin{array}{l}\text { Improved efficiency } \\
\text { of construction work }\end{array}$ & $\begin{array}{l}\text { Reduce time and } \\
\text { cost; increase } \\
\text { quality }\end{array}$ & $\begin{array}{l}\text { Reduce time and } \\
\text { cost }\end{array}$ & $\begin{array}{l}\text { Reduce time and } \\
\text { cost; increase } \\
\text { quality }\end{array}$ & $\begin{array}{l}\text { Reduce time and } \\
\text { cost }\end{array}$ \\
\hline $\begin{array}{l}\text { Environmentally } \\
\text { friendly methods }\end{array}$ & Agree & Agree & Agree & Agree \\
\hline
\end{tabular}

\subsection{Challenges of LBM Implementation}

A summary of the interviews regarding the challenges of LBM implementation is shown in Table 3. Most of the respondents stated that they did not notice LBM-technology adoption in university subjects or curriculums. Two of the respondents have mentioned that most of the interning students or new staff, who work or undergo training, were not exposed to LBM technology. Meanwhile, the consultant and developer mentioned that LBM technology has become part of the syllabus but with limited information. Hence, most of the respondents have given more information to fresh graduate or interning students when recruited.

Two of the companies noted that expert consultants introduced by government agencies have collaborated with the professional body (i.e Institution of Engineers, Malaysia) which is relating to the LBM technology. Meanwhile, the CIDB introduced experienced companies to contractors in order to encourage information exchange and knowledge sharing. Nevertheless, the developers didn't recognize the experience and expertise introduced by the government agencies.

Furthermore, a consensus was made between the contractors and developers with no discussion of LBM-technology challenges from the government. The consultant claimed that there was a discussion between the CIDB and Standard and Industrial Research Institute of Malaysia (SIRIM) regarding design and quality. Next, challenges were faced by the respondents due to a lack of government incentives and promotion. A majority of contractors (except Company 4) learned about the promotion and incentives through the CIDB's website and during licenses 
renewal. Meanwhile, the consultant and developer did not receive any incentives. Hence, there is still a lack of encouragement, promotion, and expertise regarding LBM technology implementation. Policymakers should formulate new strategies that will benefit stakeholders in LBM implementation.

Finally, the contractors, consultant, and developer faced low demand from local customers. There was low awareness toward LBM-technology implementation and LBM projects among the public.

Based on the results, the three main challenges of LBM-technology implementation are: a lack of knowledge and expertise, a lack of promotion and incentives, and a lack of local demand.

Table 3 Challenges and barriers in LBM technology implementation

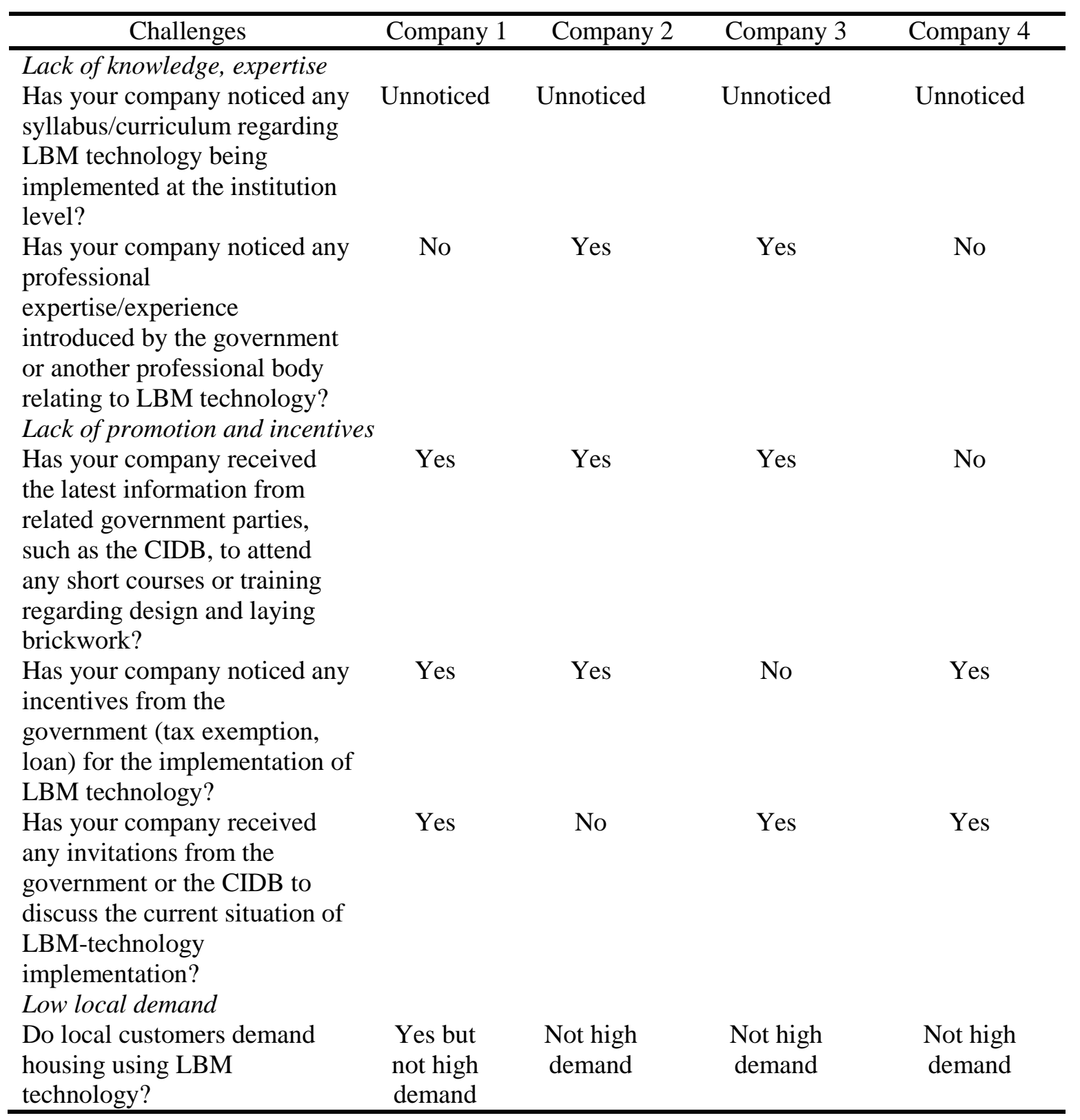

\section{CONCLUSION}

LBM technology is a construction method that is considered to be an effective way to achieve productivity and make the industry more interactive. To move forward in construction 
technology, the Malaysian government has to encourage the use of interlocking-block systems (LBM technology), which is under the Industrialized Building System category in construction. LBM technology is an alternative method with benefits in terms of quality, cost-effectiveness, productivity, and waste reduction.

To accelerate the adoption of LBM technology, the success factors need to be identified. The challenges of LBM-technology implementation must also be identified to overcome problems and improve the adoption of this technology in the future. The results of this case study indicate eight success factors: organizational resources, good team collaboration, easier methodologies, skilled labor, continuous improvement of knowledge, good work coordination, improved construction efficiency, and environmentally friendly construction methods. The results also point out three main challenges faced by industry players: a lack of knowledge and expertise, lack of incentives, and a lack of local demand. Further studies should be done to understand the success factors and challenges of LBM-technology implementation for the improvement and benefit of the construction industry.

\section{ACKNOWLEDGEMENT}

The authors wish to thank the Universiti Utara Malaysia for funding this study under Geran Penjanaan Penyelidikan Skim (SO Code: 13910).

\section{REFERENCES}

Adedeji, Y.M.D., 2012. Sustainable Housing Provision: Preference for the Use of Interlocking Masonry in Housing Delivery in Nigeria. Architecture Research, Volume 2(5), pp.81-86

Abdullah, C.S., Zulhumadi, F., Othman, A.R., 2009. Load Bearing Masonry Construction System-Its Adoption by the Construction Industry in Malaysia. Construction Research Journal, Volume 4, pp. 25-39

Abdullah, C.S., Bahaudin, A.Y., Mohd Nawi, M.N., Baluch, N.H., Kamaruddeen, A.M., Mohtar, S., Mohamed Udin, Z., Zulhumadi, F., Abu Bakar, Z., 2015. Implications of Technology Transfer in the Design and Construction of Load-bearing Masonry Buildings. Jurnal Teknologi, Volume 77 (5), pp. 127-134

Baharuddin, M.N., Bahardin, N.F., Zaidi, M.A., Yusof, M.R., Lokman, I., 2015. Identification of Critical Factors and Difficulties for Industrialised Building System (IBS) Formwork in Malaysian Construction Industry-A Literature Review. In: The $2^{\text {nd }}$ International Conference on Science and Social Research (CSSR 2015), 5-6 October 2015, Shah Alam, Selangor, Malaysia

Baharuddin, M.N., Bahardin, N.F., Zaidi, M.A., Lokman, I., Nawi, M.N.M., 2016. A Barriers and Challenging Criteria of IBS Formwork: A Current Scenario amongs Stakeholder. Revista Tecnica de la Facultad de Ingenieria Universidad del Zulia, Volume 39(9), pp.1421

Ismail, F., Yusuwan, N.M., Baharuddin, H.E.A., 2012. Management Factors for Successful IBS Projects Implementation. Procedia-Social and Behavioral Sciences, Volume 68, pp. 99107

Kamar, K.A.M., Hamid, Z.A., Alshawi, M., 2010. The Critical Success Factors (CSFs) to the Implementation of Industrialized Building System (IBS) in Malaysia. In: Proceedings: TG57-Special Track, $18^{\text {th }}$ CIB World Building Congress, CIB, Rotterdam

Lessing, J., Stehn, L., Ekholm, A., 2005. Industrialised Housing: Definition and Categorization of the Concept. In: Annual Conference of the International Group for Lean Construction: 18/07/2005-21/07/2005, pp. 471-480

Majid, S., 1997. Loadbearing Brickwork Methods Offers Advantages. Business Times, Publication Date, Volume 13(1), p. 1997 
Ramli, N.A., Abdullah, C.S., Nawi, M.N.M., 2014. Definition and New Directions of IBS Load Bearing Masonry (LBM) System in Construction Industry. Advances in Environmental Biology, Volume 8(5), pp.1864-1868

Ramli, N.A., Abdullah, C.S., Nawi, M.N.M., 2016a. Factors Influence the Adoption of Loadbearing Masonry System: A Study on Malaysia Housing Developer Firms. The Social Sciences, Volume 11(31), pp. 7423-7427

Ramli, N.A., Abdullah, C.S., Nawi, M.N.M., Bahaudin, A.Y., 2016b. Load-bearing Masonry System Adoption and Performance: A Case Study of Construction Company in a Developing Country. In: AIP Conference Proceedings. Volume 1761(1), p. 020091

Ramli, N.A., Abdullah, C.S., Nawi, M.N.M., 2017. Empirical Study of the Perceived Ease of Use and Relative Advantage on Load-bearing Masonry (LBM) Technology Adoption. In: AIP Conference Proceedings, Volume 1903(1), p. 030006

Shah Alam, S., 2009. Adoption of Internet in Malaysian SMEs. Journal of Small Business and Enterprise Development, Volume 16(2), pp. 240-255

Sharath, M.S.A.I., Vikas, V.V., Kumar, B.S.C., 2013. Sustainable Construction using Interlocking Bricks/blocks. International Journal of Applied Science, Engineering and Management, Volume 2, pp. 6-10

Thanoon, W.A., Peng, L.W., Kadir, M.R.A., Jaafar, M.S., Salit, M.S., 2003. The Experiences of Malaysia and Other Countries in Industrialised Building System. In: Proceeding of International Conference on Industrialised Building Systems, September 2003, pp. 10-11

Yin, R.K., 2015. Qualitative Research from Start to Finish. Guilford Press, New York 